\title{
Kim był Abraham i skąd pochodził? Kilka uwag na temat potencjalnych śladów tradycji o Abrahamie
}

\author{
Who Was Abraham and Where Did He Come from? \\ A Few Remarks on Potential Traces of the Abrahamic Tradition
}

\author{
JANUSZ ADAM LEMAŃSKI \\ Uniwersytet Szczeciński \\ email: lemanski@koszalin.opoka.org.pl \\ ORCID: 0000-0002-1512-997X
}

\begin{abstract}
Aвstract: Who was the "historical" Abraham and where did he come from? It is difficult to find an unambiguous answer to these questions. The article focuses on analyzing the Egyptian text from the time of Sheshonq I which mentions a place sometimes identified as "Abram's field / fort". However, this interpretation is pointed out as being uncertain and even very questionable. The next two points of analysis are biblical texts (Deut 26:5a; Gen 11:27-32). The names of Abraham's family members are toponymic (male) or symbolic (female), constituting female nicknames associated with the worship of the moon god. Their analysis suggests the region of Charan, between the Euphrates and Habur rivers, where the worship of the moon god was very popular. These areas were previously inhabited by the Amorites, and then by the Arameans. The article concludes that the "historical" Abraham may have come from the vicinity of Charan and had Amorite roots, while identification with the Arameans was only a typological element resulting from the experience of the same fate (deuteronomist). It was only later reinterpreted in favor of Jacob (cf. Gen 46:1-7), and finally in favor of Abraham in the final edition.
\end{abstract}

KeYwords: Abraham, historicity, patriarchs, Sheshonq, Charan

SŁowA KLuCze: Abraham, historyczność, patriarchowie Szeszonk, Charan

A ktualny stan badań nad tradycjami patriarchalnymi pozwala nam stwierIdzić, że postać Abra(ha)ma, wnioskując przynajmniej na podstawie wyników analizy krytycznoliterackiej tekstów biblijnych oraz z punktu widzenia badań z zakresu historii tradycji, stanowi najmłodszy składnik w tak zwanej patriarchalnej triadzie: Abraham, Izaak, Jakub². Poza Księgą Rodzaju o Abra-

1 R. Brandscheidt, Abraham. Glaubenswanderschaft und Opfergang des von Gott Erwählten (Würzburg: Echter 2009); A. Mühling, ,, Blickt auf Abraham euren Vater”.'Abraham als Identifikationsfigur des Judentums in der Zeit des Exils und des Zweiten Tempels (FRLANT 236) (Göttingen: Vandenhoeck \& Ruprecht 2011); J. Lemański, Ksiegga Rodzaju. Rozdziaty 11,27-36,43 (NKB.ST 1/2) (Częstochowa: Święty Paweł 2014) 63-85; J. Blenkinsopp, Abraham. The Story of a Life (Grand Rapids, MI, Cambridge: Eerdmans 2015). 
hamie wspomina się dopiero w okresie wygnania babilońskiego, zaś o relacjach „domu Izaaka” i „domu Jakuba” pisze już prorok Amos w VIII w. przed Chr. (Am 7,9.16). Ten sam prorok wskazuje także na zwyczaj pielgrzymowania Izraelitów do Beer Szeby (Am 5,5; 8,14)2. Mamy więc - jak się wydaje - do czynienia z jakimś śladowym i dość archaicznym świadectwem o związkach potomków Izaaka z potomkami Jakuba oraz powiązaniu ich z konkretnym miejscem w regionie Negebu. Także porównanie częstotliwości innych odniesień, z uwzględnieniem chronologii powstawania tekstów biblijnych, w których się one pojawiają, wyraźnie faworyzuje patriarchę Jakuba, a nie Abrahama, jako pierwszego protoplastę Izraela ${ }^{3}$. Nie licząc kilku nieco starszych elementów z cyklu o Abrahamie (Rdz 11,27-25,11), takich jak jego ewentualne związki etniczne z Moabitami i Ammonitami (via Lot) czy innymi ludami z Negebu (via Izmael i Ketura), reszta opowieści o tym patriarsze jest raczej wytworem inwencji literackiej i teologicznej późniejszych redaktorów Pięcioksięgu, którzy już po wygnaniu babilońskim uczynili z jakiegoś lokalnego przodka (por. Ez 33,24; Iz 51,2), mieszkającego na Negebie, blisko Beer Szeby lub w okolicach Hebronu, pierwszoplanową czy wręcz programową (por. Rdz 12,1-3) postać dla całej tradycji patriarchalnej starożytnego Izraela ${ }^{4}$.

Precyzyjne odtworzenie procesu powstawania opowieści o patriarchach, choć podejmowane są wciąż kolejne, nowe próby, zapewne nigdy nie będzie możliwe. Istnieją co prawda pewne ogólne ustalenia, które podzielają wszyscy badacze, ale co do detali, brak przekonującej rekonstrukcji rozwoju tradycji, zwłaszcza tej o Abrahamie, która umożliwiłaby pełen konsensus badawczy w tej kwestii.

W poniższym artykule zaproponowane zostanie spojrzenie na tę ostatnią tradycję nie tylko z perspektywy wyników badań krytycznoliterackich, ale przede wszystkim od strony jej potencjalnych korzeni historycznych. Ściślej mówiąc, chodzi o spojrzenie na kilka możliwych źródeł informacji dotyczących tematu ewentualnego pochodzenia patriarchy Abrahama. Pierwsze z nich ma charakter pozabiblijny (inskrypcja faraona Szeszonka I), dwa pozostałe odnoszą się do analizy danych starotestamentowych (Pwt 26,5a; Rdz 11,27-32). Prezentacja oczywiście nie jest wyczerpująca. Potencjalnych śladów „historycznego” Abrahama niewątpliwie można by szukać nie tylko w innych jeszcze tekstach biblijnych,

2 Por. J. Lemański, „W poszukiwaniu tradycji o Izaaku”, CThO 2 (2013) 63-76; idem, Księga Rodzaju. Rozdzialy 11,27-36,43, 661-663.

3 Na ten temat por. J. Lemański, „Abraham versus Jakub”, CT 88/4 (2018) 35-51. Por. także M. Köckert, „Wie wurden Abraham- und Jakobüberlieferung zu einer «Vätergeschichte» verbunden?”, HBAI 3 (2014) 43-66.

4 R.G. Kratz, „Die Verheissungen an die Erzväter. Die Konstruktion ethnischer Identität Israels”, The Politics of the Ancestors (red. M.G. Brett - J. Wöhrle) (FAT 124; Tübingen: Mohr Siebeck 2018) 35-66, zwł. 42. 
ale i poza nimi ${ }^{5}$. Proponowana tu analiza stanowi więc jedynie swego rodzaju przyczynek do dyskusji nad tymi kwestiami.

\section{Lista faraona Szeszonka $I^{6}$}

Jak to już wielokrotnie zauważano, Abraham nie jest postacią z kart wielkiej historii. Nie znajdziemy zatem informacji o nim na monumentach, w inskrypcjach i kronikach. Nie odnajdziemy nawet świadczących o nim bezpośrednio artefaktów historycznych. Był zwykłym człowiekiem, który z punktu widzenia wielkiej historii nie odegrał żadnej znaczącej roli. Dla jakiejś grupy jego późniejszych potomków był on jednak „lokalnym bohaterem”, protoplastą, pionierem, który przybył i osiedlił się na konkretnym kawałku ziemi. Z tekstów biblijnych nie trudno wywnioskować, że geograficzny rdzeń tradycji o nim łączy się z pustynią Negeb, okolicami Hebronu i Morza Martwego. Innymi słowy, z terenami pogranicza (pustynia pomiędzy Egiptem i Judeą) leżącymi na południe od Jerozolimy. Być może z tej lokalizacji wzięły się tradycje łączące go z Izmaelitami oraz potomkami Ketury czy Lota ${ }^{7}$. Tego można się domyślać, ale w jednoznaczny sposób dowieść już się dzisiaj nie da.

$\mathrm{Z}$ tego zresztą powodu nie szukamy w zasadzie zewnętrznych, bezpośrednich świadectw dotyczących historycznego Abrahama. Co najwyżej wnioskujemy coś pośrednio. Najczęściej przywoływane są teksty z Mari i Nuzi oraz kontekst kulturowy związany z półnomadycznym, pasterskim trybem życia i migracjami, jakie miały miejsce $\mathrm{w}$ drugim i pierwszym tysiącleciu przed Chrystusem na terenach Lewantu ${ }^{8}$. Na tym tle pojawia się jednak ciekawy wyjątek - dokument historyczny z czasów tzw. trzeciego okresu przejściowego w dziejach Egiptu. Chodzi o inskrypcję z Karnaku poświęconą wyprawie wojennej założyciela XXII dynastii, Szeszonka I ( $\sim 945-924$ przed Chr.), na tereny Kanaanu ${ }^{9}$. Wyprawa

5 Na ten temat szerzej I. Finkelstein - Th. Römer, „Comments on the Historical Background of the Abraham Narrative. Between 'Realia' and 'Exegetica', HBAI 3 (2014) 3-32.

6 Na temat faraona i jego związków z Palestyną por. Th. Schneider, Leksykon faraonów (Warszawa Kraków: Wydawnictwo Naukowe PWN 2001) 319-321; B. Kwiatkowski, Poczet faraonów. Życie, legenda, odkrycia (Warszawa: Iskry 2002) 566-571.

7 Por. A. de Pury, „Abraham, the Priestly Writer's 'Ecumenical' Ancestor”, Rethinking the Foundations. Historiography in the Ancient World and in the Bible. FS. J. Van Seters (red. S.L. McKenzie - Th. Römer (BZAW 293; Berlin - New York: de Gruyter 2000) 163-181.

$8 \quad$ Na ten temat por. Lemański, Księga Rodzaju. Rozdziały 11,27-36,43, 40-48.

9 K.A. Kitchen, The Third Intermediate Period in Egypt (1100-650 B.C.E.) (Warminster: Aris \& Phillips 1986) 294-300; B. Mazar, „Pharaoh Shishak's Campaign to the Land of Israel”, The Early Biblical Period: Historical Studies (red. S. Ahituv - B.A. Levine) (Jerusalem: Israel Exploration Society 1986) 39-50; Y. Aharaoni, The Land of the Bible. A Historical Geography (Philadelphia, PA: Westminster Press 1979) 323-330; J. Warzecha, Historia dawnego Izraela (Warszawa: 
ta wspominana jest także w $1 \mathrm{Krl} 14,25-25$ i potem raz jeszcze, w nieco poszerzonej wersji (jako kara Boża), w 2Krn 12,2-12 ${ }^{10}$. Oczywiście relacje te różnią się od siebie w kilku zasadniczych punktach, ale to akurat jest zrozumiałe. Autorom wszystkich tych tekstów przyświecały wszak odmienne cele propagandowe oraz ideowe. Nie znamy dokładnych przyczyn tej kampanii militarnej. Wiemy jednak, że wcześniej faraon udzielił schronienia zbuntowanemu wobec władzy Salomona Jeroboamowi, sprawcy rozpadu zjednoczonej monarchii i przyszłemu królowi Izraela $^{11}$. Niemniej, jak pisze Lester L. Grabbe ${ }^{12}$, same przyczyny, przebieg kampanii, jej charakter (jedna wyprawa czy liczne rajdy) oraz skutki są sprawą dyskusyjną i brak w tych kwestiach jakiegokolwiek konsensusu, a w konsekwencji przekonującego wyjaśnienia.

Data tej wyprawy, przy założeniu, że była to tylko jedna kampania, ustalana jest na podstawie chronologii biblijnej. Piąty rok panowania Roboama (1Krl 14,25), to około 926 r. przed Chr. Część badaczy ${ }^{13}$ wskazuje jednak na 921 r. przed Chr., przyjmując jednak, że w 926 r. Roboam dopiero zasiadł na tronie. Inni przenoszą całe wydarzenie jeszcze wcześniej, na rok 931/93014.

Według stanowiącej część inskrypcji listy miast kananejskich faraon wraz ze swoim wojskiem dotarł aż do Megiddo i Ta’anakh, czyli do granic doliny Jizreel. Potem wracał na dół poprzez Beth Szean, wzdłuż Jordanu, do Mahanaim. Stąd udał się poprzez centralną część Kanaanu na wybrzeże do Beth Horon i powrócił stamtąd na Negeb, skąd wcześniej przybył. W sumie lista zawiera 150 nazw topograficznych, w tym 70 lokalizowanych na pustyni Negeb. Niemniej Kevin A. Wilson ${ }^{15}$, który przebadał i porównał inskrypcję Szeszonka z innymi egipskimi inskrypcjami tego rodzaju, stwierdził, że raczej nie zawierają one precyzyjnych danych historycznych. Ich główny cel to gloryfikacja władcy za przeprowadzenie zwycięskiej kampanii. Listy toponimiczne podawane są na nich natomiast

Wydawnictwo UKSW 2005) 229-230; E. Lipiński, Studia z dziejów i kultury starożytnego Bliskiego Wschodu (Kraków: Nomos 2013) 186-189. Opis samego reliefu i jego najciekawszą część, jaką jest lista toponimów z Kanaanu, por. K.A. Wilson, The Campaign of Pharao Shoshenq I into Palestine (FAT 2/9) (Tübingen: Mohr Siebeck 2005) 48-65; L.D. Morenz, „Reconsidering Sheshonk's Emblematic List and His War in Palestine”, Moving across Borders. Foreiaign Relations, Religion and Cultural Interactions in the Ancient Mediterranean (red. P. Kosoulis - M. Magliveras) (OLA 159; Löwen: Peeters 2007) 101-118. Fotografia por. także TUAT NF, II, 250.

10 Nie ma wątpliwości, że w wersji biblijnej chodzi o tego właśnie faraona i tę samą kampanię wojskową; por. M. Weippert, Historisches Textbuch zum Alten Testament (Grundrisse zum Alten Testament 10; Göttingen: Vandenhoeck \&Ruprecht 2010) 228-229.

11 Lipiński, Studia, 188.

12 L.L. Grabbe, Ancient Israel. What Do We Know and How Do We Know It (New York - London: Continuum 2007) 81-83, zwł. 81.

13 J.H. Hayes - P.K. Hooker, A New Chronology for the Kings of Israel and Judah (Atlanta, GA: Knox 1988) 16.

14 K.T. Andersen, „Noch einmal: Die Chronologie von Israel und Juda”, SJOT 3/1 (1989) 42.

15 Wilson, The Campaign. 
bez jakiegoś precyzyjnego uporządkowania i koncepcji. Brak im chronologii, a nawet często pojawiają się na nich, obok miast rzeczywiście zaatakowanych czy zdobytych, takie, które nie zostały dotknięte skutkami inwazji.

Na liście Szeszonka I zwraca uwagę najpierw brak nazwy „Jerozolima”, stąd część badaczy uważa informację z $1 \mathrm{Krl}$ 14,26, o kosztownościach zabranych ze świątyni i pałacu, za rodzaj trybutu zapłaconego faraonowi, a nie łup zabrany po zdobyciu miasta ${ }^{16}$. Dla naszych badań o wiele bardziej intrygujące jest jednak to, że z jednej strony w gronie miejsc znajdujących na Negebie brakuje nazwy tak ważnego miasta, jak „Beer Szeba”, a z drugiej znajduje się na niej tajemnicze egipskie określenie $p^{3}-h a-q-r u^{\prime} a$ 'i-bi-ra-ma. Część badaczy uważa, że zwrot ten zawiera semickie słowo odpowiadające imieniu „Abram" ${ }^{17}$. Byłoby to zatem pierwsze $\mathrm{i}$ jedyne udokumentowane potwierdzenie imienia patriarchy w regionie z nim związanym, o ile nie przyjmiemy założenia, że chodzi w tym wypadku jedynie o dość popularne imię ${ }^{18} \mathrm{i}$ postać kompletnie niezwiązaną z biblijnym patriarchą.

Ponadto samą tego rodzaju imienną identyfikację egipskiego zapisu, wbrew opinii zwolenników takiej interpretacji, trudno również uznać za „entirely certain"19. Niemniej warto się jej ponownie przyjrzeć, gdyż we współczesnej dyskusji powórciła ona w nowym wariancie. Ostatnio opowiedział się za nią między innymi Ronald Hende ${ }^{20} \mathrm{i}$ to jego argumentacja zostanie tu zaprezentowana. Podana powyżej transkrypcja egipskiego zapisu jest zaproponowana właśnie przez tego autora. W nowszych wydaniach tekstu interesująca nas fraza wygląda następująco: $p^{3} h w-q-r w-{ }^{\prime}-3$ ' $w-b^{3} r^{\prime}-m$ (pisownia) $=p^{3} h q r$ 'brm (identyfikacja spółgłosek $)^{21}$, lub zapisana fonetycznie: $h a g r j-b-r-m^{22}$. Trzeba przy tym od razu zauważyć, że w obu cytowanych wersjach tekstu listy Szeszonka I brak jest identyfikacji ostatniego toponimu, a propozycja, by w egipskim zapisie widzieć imię

16 N.P. Lemche, The Israelites in History and Tradition (London - Loiusville, KY: Westminster John Knox Press 1998) 56-57.

17 Jako pierwsi zwrócili na to uwagę: J.H. Breasted, „The Earliest Occurrence of the Name of Abraham", AJSL 21 (1904) 22-36; W. Spiegelberg, Aegyptologische Randglossen zum Alten Testament (Strassburg: Schlesier \& Schweikhardt 1904) 14. Analityczne podstawy por. J.E. Hoch, Semitic Words in Egyptian Texts of the New Kingdom and Third Intermediate Period (Princeton, NY: Princeton University Press 1994) 18, 205, 235-237, 568. Według tych badaczy użyty wraz z tym imieniem i poprzedzający je rzeczownik interpretowany jest jako słowo hqqt, które oznacza ,pole” (por. ak.: eglu; aram.: haqlā; aram./etiop.: hagl; sab.: hqql). Zatem cały zapis topograficzny należy według nich tłumaczyć jako ,pole Abrama”.

18 J. Van Seters, Abraham in History and Tradition (New Haven, CT - London: Yale University Press 1975) 40-42.

19 Hoch, Semitic Words, 18.205.

20 R. Hendel, Remembering Abraham. Culture, Memory, and History in the Hebrew Bible (Oxford: Oxford University Press 2005) 48-49.

21 Weippert, Historisches Textbuch, 236.

22 TUAT NF, II, 267-268. 
„Abram”, wskazana jest jedynie w przypisie ${ }^{23}$. Niemniej - jak było już zaznaczono - mimo wszystko warto się jej uważnie przyjrzeć z uwagi na proponowany nowy wariant interpretacyjny.

$\mathrm{Na}$ początku - jak wspomnieliśmy ${ }^{24}$ - proponowano, by egipskiemu słowu $h q r$ przypisać sens ,pole”, a więc interpretować je jako odpowiednik semickiego rdzenia $h q l$. Sugerowany semicki rdzeń nie ma jednak swego odpowiednika w języku hebrajskim. Dzisiaj więc wybór pada częściej na inne możliwe znaczenie. Obecne w egipskim tekście słowo ḥqr i poprzedzający je rodzajnik można zrozumieć jako pochodną hebrajskiego czasownika $h g r$ - „opasywać, opasywać się (np. bronią), opasywać kogoś czymś”"25. Z tego powodu ostatnio proponowane jest thumaczenia tego leksemu w sensie „fortyfikacja”, „fort” (niem. Umfriedung - „ogrodzenie”; tak M. Weippert). Jak pisze R. Hendel ${ }^{26}$, sens zapisu może być zatem taki: „fort, fortyfikacja Abra(ha)ma”, czyli w skrócie „Fort Abraham". Hendel nie jest pierwszym, który zaproponował takie rozumienie całego zapisu. Zbiera on jednak argumenty za taką jego interpretacją i potem za identyfikacją tej nazwy z biblijnym patriarchą. Właściwa jest najpierw - jak pisze - geografia (Negeb). Życie patriarchy Abrahama wszak toczy się głównie $w$ tym rejonie. Ciekawa jest potem chronologia. Istnienie fortu potwierdza wspomniany dokument historyczny z czasów Szeszonka I, a więc z końca X w. przed Chr. Opisane w nim wydarzenia dzieją się krótko po poddziale monarchii Salomona, zaś za biblijnym opisem postaci Abrahama badacze już dawno doszukiwali się śladów ideologii królewskiej. Zauważano, że biblijnego Abrahama wiele łączy z biblijnym Dawidem (np. Hebron: 2Sm 2,1-4; Rdz 17,18; $23,2)^{27}$. Wreszcie swoje argumenty dodaje także archeologia ${ }^{28}$, która potwierdza istnienie gęstej sieci miast na Negebie, jak wynika to z listy Szeszonka, choć zarazem nie pozwala na ich pełną identyfikację. Tylko niektóre z odkrytych miejsc dają się bowiem precyzyjnie powiązać z nazwami z listy. Jedną z nich jest Arad, nazwany tu ,fortem wielkiego Aradu”. Badania potwierdzają w tym wypadku (i w wielu innych), że miasta na Negebie opasane były zwykle murami kazamatowymi, stąd obecność w nazwie słowa ḥagr - „opasanie”, „coś otoczone murem”, „fortyfikacja”, „fort”. Bez wątpienia chodzi o przygraniczne

23 Jako nieznane miejsce interpretował to również K.A. Kitchen (The Third Intermediate, 439 przypis 84). M. Noth („Die Wege der Pharaonenheere in Palästina und Syrien: Untersuchungen palästinischen und syrischen Städte IV: Die Schoschenkliste", Aufsätze zur biblischen Landes und Altertumskunde [red. H.W. Wolf] [BTG; Neukirchen-Vluyn: Neukirchener Verlag 1971] 83, 91) w słowie j-h-r-m (nr 71 na liście) widzi natomiast liczbę mnogą do słowa z nr. 40 (Abel).

24 Por. przypis 16.

25 KBL, I, 277.

26 Hendel, Remembering Abraham, 48.

27 M. Weinfeld, The Promise of the Land (Barheley, CA: University of California Press 1993) 222-262.

28 A. Mazar, Archaeology of the Land of the Bible 10,000-586 B.C.E. (New York: Doubleday 1990) 390-397. 
umocnienia obronne. Czy zatem wspomniany brak na liście tak ważnego w tym regionie miasta jak Beer Szeba nie powinien zastanawiać? Yohanan Aharoni ${ }^{29}$ uważa, że na bazie tradycji biblijnych (Abraham jako założyciel Beer Szeby; por. Rdz 21,22-33) trzeba identyfikować „Fort Abrama” właśnie z Tell el-Seba, fortyfikacją otoczoną murem kazamatowym ${ }^{30}$, stanowiącą pozostałości dawnej Beer Szeby z epoki żelaza.

Taka interpretacja od początku była jednak dyskusyjna ${ }^{31}$. Sam jej prekursor zresztą $^{32}$ przyznał z czasem, że egipski zapis, interpretowany przez niego jako odpowiednik imienia „Abram”, można zrozumieć także jako pochodną hebrajskiego 'abbirîm („,mocarze”) lub 'ābēlîm (,żałobnicy”?). Ponadto miejscem, z którym najpewniej wiązać można początki biblijnej tradycji o Abrahamie, jest raczej Mamre-Hebron ${ }^{33}$, a nie Beer Szeba ${ }^{34}$. Ta ostatnia może być natomiast miejscem pochodzenia tradycji o Izaaku, jedynym z trzech patriarchów, który był wyłącznie z nim związany (Rdz 26,26-33). Wspominane już wypowiedzi proroka Amosa (VIII w. przed Chr.) wskazują, że z miejscem tym, mimo późniejszych biblijnych sugestii (por. Rdz 21,22-33), łączeni byli dwaj kolejni patriarchowie (por. Am 5,5; 8,14; jako wyznacznik granicy południowej Izraela por. 2Sm 17,11; 24,2; $1 \mathrm{Krl} 5$,5). Powiązanie z nim Abrahama może być w związku z tym wtórne. W sumie nie mamy zatem żadnej przekonującej argumentacji za tym, że tekst egipski wspomina miejsce związane z biblijnym Abrahamem czy jakimś jego historycznym pierwowzorem.

29 Aharaoni, The Land of the Bible, 329. Por. wcześniej B. Mazar, „The Campaign of Pharao Shishak to Palestine", Volume du Congrès. International pour l'Étude de l'Ancien Testament, Strassbourg 1956 (VTSup 4; Leiden: Brill 1957) 57-66, zwł. 65.

30 Z. Herzog, „Tel Beersheba”, The New Encyclopedia of Archaeological Excavations in the Holy Land (red. E. Stern) (New York: Simon \& Schuster 1993) I, 167-173. Ciekawe, że Jerome MurphyO’Connor (Przewodnik po Ziemi Świętej, wyd. 2 [Warszawa: Vocatio 1999] 196-198), prezentując bardzo dobrze archeologiczne dane na temat Beer Szeby, pisze jednocześnie tak: „Zostało ono zniszczone w końcu X wieku przed Chr., w straszliwym pożarze, który prawdopodobnie związany był z najazdem na Izrael faraona Szeszonka w 925 roku. Miasto nie miało wówczas wielkiego znaczenia, nie zostało bowiem wymienione wśród zajętych miast, spisanych na ścianie świątyni w Karnaku...". W innych publikacjach można znaleźć odmienne oceny znaczenia Beer Szeby i jej fortyfikacyjnego charakteru w tym czasie („Beer Szeba”, Encyklopedia archeologiczna Ziemi Świętej [red. A. Negev, tł. O. Zienkiewicz] [Warszawa: Da Capo 2002] 55-57, zwł. 56).

31 M.G. Kyle, „The 'Field of Abram' in the Geographical List of Shoshenq I", JAOS 31 (1911) 86-92. Potem por. także Sh. Ahituv, Canaanite Toponyms in Ancient Egyptian Documents (Jerusalem: Magnes Press, Hebrew University 1984) 109.

32 J.H. Breasted, „The 'Field of Abram' in the Geographical List of Sheshonk”, JAOS 31 (1911) 290-291. Podobnie potem też Noth, „Die Wege”, 91.

33 Na temat obu miejsc D. Jericke, Die Ortsangaben im Buch Genesis. Ein historisch-topographischer und literarisch-topographischer Kommentar (FRLANT 248; Göttingen: Vandenhoeck \& Ruprecht 2013) 109-114.

34 Jericke, Die Ortsangaben, 148-150. 


\section{Abraham „Aramejczyk błądzący” (Pwt 26,5a)?}

Fragment z Pwt 26,5-10, nazywany też od czasów Gerharda von Rada „małym credo historycznym", jest raczej bardziej rytmiczną prozą niż poezją ${ }^{35}$. Stanowi on część tzw. ceremonii ofiarowania pierwocin (Pwt 26,1-11) ${ }^{36}$. Całość od dawna uważana była za tekst, który powstawał co najmniej w kilku etapach redakcji. Główna uwaga badaczy skupiała się jednak przede wszystkim na Pwt $26,5-9 / 10^{37}$. O ile G. von Rad widział w nim fragment archaicznego wyznania wiary, którego składowe wyznaczały konstruowanie tematów całego Sześcioksięgu (Hexateuch), o tyle późniejsze badania znacznie odmłodziły ten tekst ${ }^{38}$, dostrzegając w nim cechy „editorial work”, zwłaszcza w wierszach 5-9 $9^{39}$. To, co niewątpliwie jest w tym tekście starsze (w. 5aA.10a), stanowi dychotomiczne przeciwstawienie (,ojciec mój [niegdyś!] Aramejczyk błądzący [5aA]...Teraz oto pierwociny plonów ziemi, które dałeś mi. O Jhwh..." [10a]), które zostało w okresie po wygnaniu babilońskim uzupełnione o dodatkowe tematy, wyznaczające w istocie główne idee późniejszej tradycji o patriarchach, exodusie i podboju ${ }^{40}$. Wskazuje na to nie tylko aktualna wiedza o powstaniu Pięcioksięgu, ale i charakterystyka samej wypowiedzi z Pwt 26,5-10 (alternacja: ja - my; por. w. 5.10 i w. 6-9) ${ }^{41}$. Tekst ten (Pwt 26,5aA.10a) niekoniecznie musi stanowić jakiś bardzo archaiczny rdzeń, choć na pewno jest on starszy niż reszta perykopy, stanowiąca jego uzupełnienie o kilka dodatków (w. 5-9 ${ }^{42}$.

Nas interesuje tu przede wszystkim fraza: 'arammî 'ōbèd 'ābî, uważana za taką najstarszą część tej perykopy. W zdaniu tym wyraźnie widoczna jest aliteracja oparta na spółgłosce alef. Zawiera ono niejasny co do znaczenia wyraz 'ōbe $d^{43}$. Już samo zestawienie „mój ojciec” - „Aramejczyk/był Aramej-

35 J.R. Lundbom, Deuteronomy. A Commentary (Grand Rapids, MI, Cambridge: Eerdmans 2013) 721.

36 E. Nielsen, Deuteronomium (HAT 1/6; Tübingen: Mohr \& Siebeck 1995) 235: ,liturgische Anhang”.

37 A.D.H. Mayes, Deuteronomy (Grand Rapids, MI, London: Eerdmans 1981) 332.

38 Na ten temat por. E. Otto, Deuteronomium 23,16-34,12 (HThKAT; Freiburg - Basel - Wien: Herder 2017) 1880-1885.

39 Mayes, Deuteronomy, 332-333; Otto, Deuteronomium 23,16-34,12, 1881, 1886, 1893.

40 Teza o to tym, że przestrzeń pomiędzy wierszami 5 a 10 była pierwotnie wypełniona innym tekstem niż obecnie, nie łączącym początków wiary w Jhwh z Mojżeszem i exodusem, nie znalazła zbyt wielu zwolenników. Postawił ją M.A. Beek, „Das Problem des aramäisches Stammvaters (Deut XXVI 5)", OS 8 (1950) 193-212.

41 Nielsen, Deuteronomium, 236, 241.

42 M. Rose, 5. Mose. Teilband 2: 5 Mose 1-11 und 26-34. Rahmenstücke zum Gesetzeskorpus (ZBK. AT 5.2) (Zürich: Theologischer Verlag 1994) 350-363, zwł. 363: graficzna prezentacja czterech kolejnych warstw redakcyjnych.

43 Na temat interpretacji tego zdania, poza komentarzami por. także S. Kreuzer, Die Frühgeschichte Israels in Bekenntnis und Verkündigung des Alten Testaments (BZAW 178; Berlin - New York: de Gruyter 1989) 161-166; A. Schüle, Israels Sohn-Jahwes Prophet. Ein Versuch zum Verhältnis von 
czykiem" budzi wiele kontrowersji, a zrozumienie właśnie tego oświadczenia ma wpływ na tłumaczenie wspomnianej formy 'ōbéd. Może ona bowiem oznaczać najpierw nieosiadły tryb życia, nieustanną wędrówkę - bezdomność, jak również wygnanie, ucieczkę przed kimś. Odpowiada to znanemu z mezopotamskich inskrypcji stylowi życia Aramejczyków, jak i półnomadycznemu stylowi życia patriarchy Jakuba (por. Oz 12,13). Pozabiblijne relacje o Aramejczykach nie przypisują im dobrej renomy. Uchodzą oni w nich za „zbiegów” i „łupieżców”44, co zasugerowało niektórym badaczom możliwość zrozumienia biblijnego 'ōbēd nawet w sensie „zbiegły/uciekający Aramejczyk” (ang. a fugitive Aramaean) ${ }^{45}$.

$\mathrm{Z}$ drugiej strony czasownik ten może przyjąć też inny sens: zatracić się, zginąć, spowodować czyjś upadek, prowadzić do czyjejś zguby. Jest on zatem dwuznaczny ${ }^{46}$. Jeśli w istocie utożsamić protoplastę narodu wybranego, a wraz z nim początki Izraela, z Aramejczykami, to najbardziej pasowałoby tu rozumienie czasownika w sensie „wędrujący" ${ }^{47}$. Takie znaczenie odzwierciedla nomadyczny styl życia plemion aramejskich, przypisywany zwykle także patriarchom. Jak pisał jednak już dawno John Van Seters ${ }^{48}$, w życiu Abrahama znajdujemy zasadniczo tylko jeden nomadyczny detal: ,mieszkanie w namiocie”, które ponadto bardziej pasuje do I niż II tysiąclecia przed Chrystusem. Poza tym patriarcha opisywany jest w Biblii Hebrajskiej raczej jako gēr -,obcy rezydent”, a sam autor biblijny jest bardziej zainteresowany tematem związanym z osiadłym, a nie nomadycznym stylem życia, na co wskazuje dominująca w cyklu o Abrahamie i potem kwestia dziedziczenia ziemi. $Z$ tego względu wielu badaczy pierwotne i właściwsze odniesienie dla deklaracji z Pwt 26,5aA („,ojciec mój Aramejczyk błądzący/zagubiony) postrzegało w osobie Jakuba, a nie Abrahama (por. Oz 12,13-14 i Pwt 26,5a.8). Z drugiej strony fakt, że przez 20 lat Jakub był ba-

kanonischer Theologie und Religionsgeschichte anhand der Bileam-Perikope (Num 22-24) (ATM 7; München: LIT 2001) 149-152.

44 Tekst z czasów Sargona II (kol. 7,57-66.69-71) nazywa ich „rasą łupieżców”; por. C.J. Godd, „Inscribed Prisms of Sargon II from Nimrud”, Iraq 16 (1954) 173-201. Tak zwany „Cylinder Taylora” z czasów Sennacheryba (kol. 5.11) określa ich z kolei jako „zbiegłego Aramejczyka, uciekiniera, mordercę i łupieżcę”. W podobny sposób, jako „łupieżców”, określa się w listach z el-Amarny (EA 68; 185; 186) także grupy banitów nazywane habbiri (SA-GAZ); por. D.D. Luckenbill, „The 'Wandering Aramaean”', AJSL 36 (1919-1920) 281-312; N.P. Lemche, „Habiru, Hapiru”, The Anchor Bible Dictionary (red. D.N. Freedman) (New York: Doubleday 1992) III, 6-10.

45 W polskim tłumaczeniu anglojęzycznej pozycji z 1957 roku (strona 238) mamy wariant „błądzący”; por. W.F. Albright, Od epoki kamiennej do chrześcijaństwa (tł. E. Zwolski) (Warszawa: Pax 1967) 195.

46 KBL, I, 3-4; por też R.D. Nelson, Deuteronomy. A Commentary (Louisville, KY, London: Westminster John Knox Press 2002) 304; D.L. Christensen, Deuteronomy 21:10-34:12 (WBC 6B; Nashville, TN: Thomas Nelson Publishing 2002) 637.

47 Na ten temat Lipiński, Studia, 331-334. Por. także Christensen, Deuteronomy 21,10-34,12, 631.

48 Van Seters, Abraham, 16. 
nitą, uciekinierem żyjącym z dala od Ziemi Obiecanej, także nie czyni z niego nomady czy półnomady. Stąd przywołana przez Edwarda Lipińskiego ${ }^{49}$ sugestia (L. Segonda), by czasownik rozumieć w sensie „koczujący”, z odniesieniem do języka hodowców. Propozycja ta choć ciekawa, nie ma jednak dostatecznego uzasadnienia. Faktem jest jednak, że język mógłby tu nawiązywać do pasterskiego stylu życia przodków ${ }^{50}$.

Koniugacja qal rdzenia ' $b d$ ma jednak - jak zauważyliśmy - również sens „być zagubionym, zatracić się, prowadzić do zguby” (Lb 17,27; Iz 27,13; 41,11; 57,1; Prz 31,6; Hi 29,13). Zastosowana do zwierząt, przyjmuje sens „błądzić, zagubić się" (1Sm 9,3.20; Ps 119,176; Jr 50,6; Ez 34,4.16; Hi 31,19) ${ }^{51}$. Czasownik ten używany jest wtedy w sytuacjach, gdy owca gubi swoje stado. Stąd inna popularna sugestia przytaczana przez E. Lipińskiego, a mianowicie thumaczenie: „błąkać się" (hebr. 'ābad) ${ }^{52}$. Takie znaczenie łączyłoby się z akadyjskim, nieprzechodnim czasownikiem abātu - „zniszczyć”, ,zginąć”. Taka interpretacje czyni z przodków Izraela - jak zauważa nasz autor - Aramejczyków trudniących się hodowlą zwierząt (por. Rdz 47,3). Czy to jednak aby na pewno stanowi treść biblijnej deklaracji?

Interpretacja tego rodzaju wydaje się podporządkowywać znaczenie analizowanego hebrajskiego słowa przyjętej z góry tezie. Zakłada się w niej, że Izraelici są w istocie potomkami Aramejczyków, a wypowiedź nawiązuje do półnomadycznego trybu życia hodowców małej trzody. Nie można jednak zignorować wspomnianego alternatywnego znaczenia tego słowa (,zatracić się, zginąć, spowodować czyjś upadek, prowadzić do czyjejś zguby"). Także w tym aspekcie sytuacja życiowa domniemanego patriarchy - praojca Izraela, lepiej pasuje do Jakuba niż do Abrahama. Niemniej, choć Księga Rodzaju opisuje Jakuba jako uciekiniera, a potem migranta ( $\operatorname{Rdz} 28-35 ; 46,1-7)$, to nigdy nie nazywa się go „zagubionym” czy „błądzącym”53. Z drugiej zaś strony to Abraham mówi o sobie jako o wędrowcu zmierzającym w nieznane, błądzącym, prowadzonym jednak przez Boga i jedynie w nim pokładającym swoje nadzieje (por. Rdz 20,13) . $^{54}$ Czy w związku z tym możemy mówić o późniejszej reinterpretacji tradycji Jakubowej na rzecz Abrahama? Takie sugestie również się pojawiają i wydają się w dużej mierze przekonujące. Być może jednak autor biblijny pierwotnie nie miał tu na uwadze żadnego patriarchy znanego z Księgi Rodzaju. Jeśli sama deklaracja tego rodzaju jest w istocie archaiczna, jak chce część badaczy, to nie

\footnotetext{
49 Lipiński, Studia, 332.

50 M. Buber, „The Prayer of the First Fruits”, On the Bible (red. N. Glatzer) (New York: Schocken 1968) 122-130, zwł. 127.

51 KBL, I, 3-4.

52 Tak m.in. Nielsen, Deuteronomium, 235.

53 Lundbom, Deuteronomy, 726.

54 Na ten temat por. Lemański, Księga Rodzaju. Rozdziały 11,27-36,43, 431.
} 
o Jakubie czy Abrahamie była w niej mowa, ale o ogólnie rozumianym pochodzeniu przodków ze Wschodu ${ }^{55}$.

Dla egzegety najważniejsze jest ustalenie, jakie znaczenie ma dane słowo w najbliższym mu kontekście literackim i teologicznym. Zatem imiesłów 'ōbēd (rdzeń 'bd) w Księdze Powtórzonego Prawa zawsze dotyczy osoby (por. Pwt 4,26; $7,20 ; 8,19 ; 28,20.22 ; 30,18)$ i przyjmuje wtedy najczęściej sens ,ginący”. Wyjątek to Pwt 32,28, gdzie rdzeń ten opisuje sytuację bycia głuchym na rady. Nie ma zatem powodów, by nie uznać, że w Pwt 26,5aA („ojciec mój, Aramejczyk...”), gdzie imiesłów ten występuje w koniugacji qal w stronie czynnej, również ma sens ,ginący” i oznacza zatracenie się jakiejś osoby ${ }^{56}$. Zachodząca w tekstach łączonych z P wyraźna ,arameizacja” rodziny patriarchalnej mogła z czasem budzić kontrowersje, ze względu na odmienne, późniejsze losy Izraela i Aramu. Czy mamy tu zatem do czynienia z późniejszą krytyką takiej ,arameizacji” rodziny patriarchalnej dokonanej przez P? Tego nie można być pewnym ${ }^{57}$.

Faktem jest, że listy genealogicznie w Księdze Rodzaju precyzyjnie odłączają nawet symbolicznych przodków Izraela (Arpachszad, Szelach, Eber) od linii Arama, przodka Aramejczyków (por. Rdz 10,21-25). Etnicznym określeniem 'ărammî opisywani są jedynie Betuel (Rdz 25,20) i Laban (Rdz 28,5; 31,20.24), nigdy zaś Jakub czy tym bardziej Abraham. $Z$ drugiej strony autorzy biblijni wyraźnie wskazują na związki etniczne przodków Izraela z Aramejczykami (por. $\operatorname{Rdz} 24,4.10 ; 25,20)^{58}$. Syn Rebeki i prawnuk Teracha uważany jest więc pośrednio za Aramejczyka, który - mimo dwudziestoletniej migracji na dawne rodzinne tereny - wraca z czasem do swojej nowej ojczyzny (Rdz 32,24-32; 35,9-10), oddzielając się ostatecznie od swoich aramejskich korzeni. Taka identyfikacja być

55 Odnotować należy próbę alternatywnego zrozumienia całej deklaracji. Wyznanie z Pwt 26,5a odniesione zostało w niej do mowy Mojżesza skierowanej w imieniu Izraela do „braterskiego” Edomu (Lb 20,14-16) (tzw. tradycja Kadesz). W tekście tym doszukiwano się korzeni całego credo i źródła utożsamienia przodków Izraela z Aramejczykami. Jednak w obu tekstach zastosowane są odmienne czasowniki opisujące tryb życia przodków; por. Nielsen, Deuteronomium, 241. Również nieco młodsza teza, że Aram w roli najbliższego krewnego został z czasem zastąpiony w Księdze Rodzaju przez Edom, także nie ma podstaw w tekście biblijnym; stawia ją Y. Zakovitch, „'My Father Was a Wandering Aramean' (Deuteronomy 26:5) or 'Edom Served My Father'?”, Mishneh Todah. Studies in Deuteronomy and Its Cultural Environment. FS. J.H. Tigay (red. N.S. Fox et al.) (Winona Lake, IN: Eisenbrauns 2009) 133-137. Może zatem chodzić tu wyłącznie o luźną, etniczną deklarację bez konkretnych, personalnych odniesień; tak Otto, Deuteronomium 23,16-34,12, 1893-1894.

56 Otto, Deuteronomium 23,16-34,12, 1874.

57 Krytycznie o tej tezie Otto, Deuteronomium 23,16-34,12, 1895, ze wskazaniem na A. de Pury'ego i T. Römera, jako jej zwolenników.

58 To wystarczające przykłady, by uznać za nietrafioną tezę o pozytywnym nastawieniu środowiska kapłańskiego do etnicznych związków z Aramejczykami i negatywnym podejściu do tej kwestii przez późniejszych redaktorów; tak D. Rom-Shiloni, „When an Explicit Polemic Initiates a Hidden One: Jacob's Aramaic Identity", Words, Ideas, Worlds. FS. Y. Amit (red. A. Brenner - F.H. Polak) (Sheffield: Sheffield Phoenix Press 2012) 206-235; por. też Otto, Deuteronomium 23,16-34,12, 1895. Z chronologii tekstów wynika raczej coś odwrotnego. 
może byłaby trudna w czasach monarchii ze względu na wrogość obu nacji na przestrzeni od X do VIII w. przed Chr. Czy to oznacza zatem, że cała wypowiedź musi być bardzo archaiczna ${ }^{59}$ i należałoby ją umieścić jeszcze $\mathrm{w}$ okresie przedmonarchicznym? Niekoniecznie. Z czasem te złe konotacje historyczne mogły ulec zmianie. Równie dobrze można odczytać tę „etniczną” deklarację jako wypowiedź z okresu końca monarchii lub jeszcze późniejszą. Taką datację sugeruje się dzisiaj najczęściej. Zdaniem Martina Rosego ${ }^{60}$ wzajemna wrogość pomiędzy Izraelitami i Aramejczykami zakończyła się po 732 r. przed Chr. Wtedy to Asyryjczycy zniszczyli królestwo Aramu i po raz pierwszy zastosowali masowe wysiedlenia podbitej ludności. Aramejczycy stali się wówczas ,przymusowymi” kosmopolitami, a ich język ewoluował w swoistą lingua franca tej epoki. Krótko potem ten sam los spotkał Izraelitów (722/721 przed Chr.). To wówczas, w poczuciu wspólnoty losów, obie nacje stały się sobie bliskie, a język aramejski stał się nawet językiem wygnańców z Izraela, a potem także z Judy (597/587 przed Chr.). Zdaniem M. Rosego, to właśnie w tej sytuacji geopolitycznej i społecznej szukać należy duchowego klimatu dla deklaracji z Pwt 26,5aA („ojciec mój, Aramejczyk błądzący...”). Aramejczycy funkcjonują w niej jako „Typos Heimatlosen" - typ ludzi pozbawionych ojczyzny. Zatem w całej deklaracji jego zdaniem - nie chodzi ani o Jakuba (por. Oz 12,13), ani o Abrahama (por. Ez 33,24; Iz 51,2), lecz o ogólną typologię. „Mój ojciec” to w istocie wyłącznie deklaracja, że „początki Izraela były bez realnej przyszłości”“61. Pwt 26,5.10 wyraźnie akcentują jednak kontrast pomiędzy sytuacją przodków i obecną sytuacją ich potomków. Ofiara pierwocin - niewątpliwie starsza niż prawodawstwo deuteronomistyczne - stanowi jedynie okazję do zadeklarowania swej wdzięczności Bogu właśnie za tę obecną sytuację, lepszą niż rokowały to początki tego narodu. Bez trudu można ten wyraz wdzięczności przypisać deuteronomiście. Na resztę perykopy (w. 5aB-9.10b.11) składa się już język i styl późniejszej redakcji deuteronomistycznej ${ }^{62}$ lub postdeuteronomistycznej ${ }^{63}$.

Kłopot z identyfikacją przodków Izraela z Aramejczykami mieli już starożytni tłumacze ${ }^{64}$. Zatem również i oni rozumieli, że deklaracja o aramejskim przodku nie musi być brana nazbyt dosłownie, tym bardziej że Księga Rodzaju nie

59 Mayes, Deuteronomy, 334; J.H. Tigay, Deuteronomy (JPS Torah Commentary; Philadelphia, PA: Jewish Publication Society 1996) 240; Christensen, Deuteronomy 21,10-34,12, 637; ten ostatni ze wskazaniem na J.C.L. Gibsona (,Observations on Some Important Ethnic Terms in the Pentateuch”, JNES 20 [1961] 229-234; idem, „Light from Mari on the Patriarchs”, JSS 7 [1962] $44-62$ [na temat proto-aramejskiego pochodzenia patriarchów]).

60 Rose, 5. Mose, 361; podobnie potem także Otto, Deuteronomium 23,16-34,12, 1894-1895.

61 Rose, 5. Mose, 362.

62 Mayes, Deuteronomy, 333; Otto, Deuteronomium 23,16-34,12, 1881 (ze wskazaniem dodatkowo na H.D. Preussa, U. Rüterswördena, T. Römera).

63 Rose, 5. Mose, 363.

64 Nielsen, Deuteronomium, 236; Otto, Deuteronomium 23,16-34,12, 1875. 
nazywa wprost żadnego z przodków Aramejczykiem. W Septuagincie czytamy zatem: „mój ojciec opuścił Syrię...” (syrian apebalen ho pater mou). Być może reinterpretacja tego rodzaju powstała wyłącznie pod wpływem kontekstu (kolejne zdanie mówi o ,zejściu do Egiptu”) ${ }^{65}$, ale nie można także wykluczyć, że chodzi tu o świadomą próbę zatarcia oryginalnych konotacji i wykluczenie etnicznych związków z Aramejczykami ${ }^{66}$.

Wulgata rozumie to jeszcze inaczej: „Syryjczyk prześladował ojca mego...” (Syrus persequebatur patrem meum). W tym samym kierunku poszły także Targumy (TgOnk; TgNeof) i średniowieczni komentatorzy żydowscy. Raszi, myśląc o relacjach Jakub - Laban, rozumiał całą deklarację w sensie: „Syryjczyk (= Laban) zniszczył mego ojca"67. W każdym razie, mając na uwadze oba przypadki starożytnej reinterpretacji, nie jesteśmy w stanie jednoznacznie stwierdzić, że oryginalnie w istocie chodziło o relacje Laban - Jakub i przechodni sens czasownika ('bd ${ }^{68}$. Choć obie interpretacje mieściłyby się w historycznych realiach z X-VIII w. przed Chr. i w kontekście stosunków, jakie panowały pomiędzy Izraelem i Aramejczykami (por. $2 \mathrm{Sm} 8,6 ; 1 \mathrm{Krl} \mathrm{15,18-20;Am} \mathrm{1,3-5),} \mathrm{to} \mathrm{od} \mathrm{strony}$ językowej i gramatycznej oba starożytne thumaczenia są wysoce niezadowalają$\mathrm{ce}^{69} \mathrm{i}$ mamy w nich ewidentnie do czynienia z próbami interpretacji niewygodnej tradycji o aramejskich konotacjach przodków Izraela w świetle późniejszej, kanonicznej wersji tradycji o Abrahamie i Jakubie.

Co zatem wynika $z$ aktualnej wiedzy na temat pochodzenia i znaczenia deklaracji z Pwt 26,5a? Może ona równie dobrze odzwierciedlać ,archaiczną" tradycję o związkach etnicznych przodków narodu wybranego z Aramejczykami, jak i stanowić znacznie młodszą deklarację o „wspólnocie losów”, „typ” kogoś pozbawionego nadziei na przyszłość. Następnie określenie „Aramejczyk” może równie dobrze stanowić wspomniany, ogólnie rozumiany „typ”, jak i odnosić się do konkretnego przodka - Jakuba. Ta pierwsza, konkretna reinterpretacja na rzecz Jakuba, dokonała się jednak dopiero później poprzez dodanie nowych elementów do credo (w. 5aB-9.10b.11; por. Rdz 46, 2-7; 47,4.3-4.9). Kolejna reinterpretacja całej formuły dokonała się, gdy następne redakcje dopasowały ostatecznie kontekst opowiadania o Abrahamie do możliwości zrozumienia jej w odniesieniu do tego patriarchy (por. Rdz 12,1-3; 12,10-20). Jednak - zdaniem większości badaczy - pierwotnie formuła związana była najpierw z tradycją

65 Tak J.W. Wevers, Notes on the Greek Text of Deuteronomy (SBL.SCSS 39; Atlanta, GA: Scholars 1995) 404.

66 Tak już R.A. Bowman, „Arameans, Aramaic, and the Bible”, JNES 7 (1948) 68, przypis 12.

67 Podaję za Lundbom, Deuteronomy, 726.

68 Tak, jak sugeruje to np. S. Norin, „Ein Aramäer, dem Umkommen Nahe - ein Kontext der Forschung und Tradition", SJOT 8 (1994) 87-104.

69 Tak Rose, 5. Mose, 361. Autor nie uzasadnia swojej opinii, ale chodzi bez wątpienia zarówno o niemające potwierdzenia w tekście hebrajskim słowa Syria/Syryjczyk, jak i czasownikową reinterpretacja hebrajskiego imiesłowu 'ōbe d. 
o Jakubie, zapisaną w Rdz 46,1-5a ${ }^{70}$. Wyraźnie akcentowany kontrast sytuacji opisanej w wierszu 5aA (sytuacja błądzącego, zagubionego przodka) i w wierszu 10a (obecna sytuacja uczestnika kultu, prowadzącego spokojny, osiadły tryb życia ${ }^{71}$, a więc w pierwotnych elementach tej perykopy, pozwala sądzić, że w istocie przywołuje się tu pewnego rodzaju wspólnotę losów Izraelitów i Aramejczyków, ich wspólne historyczne doświadczenie, które z czasem (późniejsze teksty) mogło doprowadzić do widocznej w tradycji patriarchalnej ,arameizacji” rodziny patriarchalnej ${ }^{72}$. Czy to oznacza, że oryginalnie przodkowie Izraela nie mieli żadnych etnicznych związków z Aramejczykami i biblijne konotacje tego rodzaju są jedynie efektem pracy kolejnych autorów Pięcioksięgu? Na to pytanie odpowiedzi może udzielić analiza imion związanych z członkami rodziny Abrahama.

\section{Toponimiczna rodzina Abrahama ( $R d z$ 11,27-32)}

W klasycznym rozumieniu perykopa składa się z materiału P (w. 27.31-32) i nie-P (w. 28-30) ${ }^{73}$. Autorzy kapłańscy kontynuują tu niejako swoją genealogię z Rdz 11,10-26. Z tego kontinuum wynika, że rodzina niejakiego Teracha, składająca się z trzech synów i wnuka, będących potomkami noszących symboliczne imiona przodków wywodzących się od Sema przez Arpachszada, Szelacha, Ebera, Pelega aż po Seruga, Nachora i wspomnianego Teracha, wyruszyła z Ur chaldejskiego w kierunku Kanaanu. Z niewiadomych przyczyn zatrzymała się jednak w Charanie. Tekst nie-P uzupełnia te informacje o szczegóły dotyczące małżeństw poszczególnych synów Teracha.

Poza wprowadzeniem (Rdz 11,27-32) i nakazem zerwania $\mathrm{z}$ rodziną oraz ziemią ojczystą (Rdz 12,1; 15,7), patriarcha Abraham ukazany jest jako postać alochtoniczna. Wyrusza z Ur (tj. z Charanu?) do Kanaanu, by tam osiąść na stałe. Poprzez opowiadanie Abraham - Lot, uważane często za najstarszy rdzeń tradycji o Abrahamie ${ }^{74}$, patriarcha nabiera autochtonicznych cech, uchodząc za kogoś

70 Na temat takiej kolejności reinterpretacyjnej por. Otto, Deuteronomium 23,16-34,12, 1897; Kratz, „Die Verheissungen”, 42. Ten ostatni ze wskazaniem na: E. Blum, Die Kompositon der Vätergeschichte (WMANT 57; Neukirchen-Vluyn: Neukirchener Verlag 1984) 307-311; M. Köckert, Vätergott und Väterverheissungen: Eine Auseinandersetzung mit Albrecht Alt und seinen Erben (FRLANT 142; Göttingen: Vandenhoeck \& Ruprecht 1988) 65.

71 P.A. Altmann, „Feast, Femine and History: The Festival Meal Topos and Deuteronomy 26,1-15”, ZAW 124 (2012) 555-567.

72 Otto, Deuteronomium 23,16-34,12, 1896.

73 Por. Lemański, Księga Rodzaju. Rozdziały 11,27-36,43, 90-91; Mühling, ,, Blickt auf Abraham”, 35 + przypis 48 .

74 Na ten temat por. dyskusję w: Mühling, ,, Blickt auf Abraham”, 41-46. 
mieszkającego od dawna w tym regionie. Wywodzenie jego korzeni etnicznych i geograficznych z Ur w Mezopotamii (Rdz 11,28.31) bez wątpienia stanowi element identyfikacyjny dla deportowanych tam mieszkańców Judei. Razem z „,nakazem” wymarszu do Ziemi Obiecanej i związanymi z tym obietnicami (Rdz 12,1-4), tworzy się model exodusu, który „rodzina” Abraham realizuje na drodze z Mezopotamii do Kanaanu (por. Rdz 15,7). Ta koncepcja nie zaskakuje, jeśli spojrzymy na nią z perspektywy teologii „,nowego-exodusu”, znanej z tekstów Deutero-Izajasza i obecnych w nich wzmianek o Abrahamie (Iz 41,8-9; 51,2; potem także 29,$22 ; 63,16)$. Abraham pod koniec wygnania babilońskiego jawi się dla grupy entuzjastów powrotu z wygnania babilońskiego (tzw. Gola) jako przykład i zarazem drogowskaz tego, co robić w sytuacji, gdy otwiera się perspektywa powrotu do ziemi przodków ${ }^{75}$. Można zakładać, że taka typologiczna koncepcja wyrosła na bazie starszej tradycji zawartej na przykład w opowiadaniu Abraham - Lot (por. Ez 33,24; Rdz 13) ${ }^{76}$.

Czemu służył zatem postój w Charanie (Rdz 11,31b.32; 12,4b.5)? Tekst biblijny tego nie precyzuje, a sama konstrukcja tekstu kanonicznego budzi wręcz wątpliwości, co do tego, skąd ostatecznie pochodzi rodzina patriarchy? Wybór Charanu jako miejsca pochodzenia mógł dokonać się ze względu na powiązanie tradycji o Abrahamie z tradycją o Jakubie (Rdz 27,43; 29,4: miejsce zamieszkania Labana). Badacze sądzą jednak, że Charan to raczej wtórny motyw we wspomnianej tradycji o Jakubie ${ }^{77}$. Z drugiej strony miasto już w czasach starobabilońskich było ważnym miejscem postoju na drodze handlowej z Ur do Anatolii i jego wzmianka w tym miejscu jest jak najbardziej logiczna. Ze zrozumiałych względów w czasach kończącego się wygnania babilońskiego i potem ważniejszym „miejscem pochodzenia” stało się jednak Ur chaldejskie (por. Ne 9,7). Ono bowiem stanowiło bliższy punkt odniesienia dla deportowanych tam mieszkańców Judei. Można przypuszczać, że Charan i Ur to dwa różne punkty wyjścia związane z dwiema różnymi kręgami pielęgnującymi tradycję o Abrahamie, a co za tym idzie, dwie różne tradycje literackie (warstwy literackie). Przy czym należy pamiętać, że Ur zaczęło być określane mianem „chaldejskie” od czasów Nabopolassara (626-605 przed Chr.). Miasto zyskało ten tytuł w związku z chaldejską dynastią (,Miasto Chaldejczyków”) ${ }^{78}$.

75 W opozycji do tzw. „ludu ziemi”, przedstawiciele Gola zreinterpretowali postać Abrahama jako pierwszego ,pielgrzyma” przybywającego z Mezopotamii, znak reprezentujący symbolicznie drogę exodusu; por. J.-L. Ska, „Essai sur la nature et signification du cycle d'Abraham (Gn 11,27-25,11)”, Studies in the Book of Genesis. Literature, Redaction and History (BETL 155; Leuven: University Press 2001) 153-177, zwł. 174.

76 Mühling, ,Blickt auf Abraham”, 84-90.

77 Blum, Die Komposition, 164-167, 343-344.

78 A. Berlejung, „Geschichte und Reliogionsgeschichte des antiken Israels”, [w:] Grundinformation Altes Testament (red. J.C. Gertz) (Göttngen: Vandenhoeck \& Ruprecht 2006) 59-192, zwł. 113. 
Sama analiza ${ }^{79}$ męskich imion członków rodziny Abra(ha)ma (Rdz 11,27-32): Terach, Nachor, Haran, sugeruje nie tylko ich pierwotne, toponimiczne znaczenie, ale i wskazuje na związki z tak zwanym regionem syromezopotamskim, położonym w okolicach miasta Charan pomiędzy rzekami Eufrat i Habur ${ }^{80}$. Z tego rejonu pochodzili - według autorów biblijnych - domniemani krewni Abrahama $(\operatorname{Rdz} 11,31 ; 24,10 ; 28,2 ; 29,4-5)$. Na uwagę zasługuje fakt, że sama ścisła rodzina Abrahama składa się standardowo z ojca i trzech synów (por. synowie Adama: Kain, Abel i Set; synowie Noego: Sem, Cham, Jafet; podobnie zresztą jest także w tradycji greckiej: Deukalion - grecki Noe - też miał trzech snów, praojców ludów greckich: Dorów, Jonów i Etolczyków) ${ }^{81}$. W genealogii Abrahama wszystkie trzy imiona jego najbliższych krewnych, jak wspomnieliśmy, mają charakter toponimiczny.

Taki sam charakter ma już również imię jego praprzodka - Seruga (Rdz 11,22). W ten sposób (Sarūgi) w tekstach z epoki Ur III określa się miejsce położone pomiędzy Charanem i Karkemisz ${ }^{82}$. Jego syn ma na imię Nachor. Tak nazywa się zarazem dziadek i potem brat Abrahama (por. Rdz 11,22-23.27). Imię ojca - Teracha - odpowiada nazwie Til ( $\breve{s} a)$ Turāhi, miejscu położonemu nad rzeką Balik w pobliżu Charanu ${ }^{83}$. Wspomniane imię Nachor to kolejny topo$\operatorname{nim} \mathrm{z}$ tego samego regionu. Teksty z II/I tysiąclecia przed Chrystusem sugerują różne warianty tej nazwy. Staroasyryjskie i starobabilońskie podają nazwę Nahur, miejsce znajdujące się na wschód od Charanu (Harrān), tuż przy rzece Habur. Teksty starobabilońskie wspominają także nazwę Nehrija i Tell Nahiri, tekst biblijny zaś - „miasto Nachora” (Rdz 24,10). Imię trzeciego z synów Teracha prawdopodobnie pochodzi wprost od nazwy Charan (harrānu - akadyjskie „droga”; „podróż”; „karawana”" ${ }^{44}$ - jak wspomnieliśmy - ważnego miejsca postoju na drodze karawanowej pomiędzy górnym Eufratem i Tygrysem, położonego na skrzyżowaniu głównych szlaków wiodących z północy na południe i ze wschodu na zachód ${ }^{85}$. Imię osoby i toponim różni jedynie pierwsza litera

79 Por. Lemański, Księga Rodzaju. Rozdziały 11,27-36,43, 92-100

80 Por. D.E. Fleming, „Mari and the Possibilities of Biblical Memory”, RA 92 (1998) 41-78; J.-M. Durrand, „Réalités amorrites et traditions bibliques”, $R A 92$ (1998) 3-39. Z wcześniejszych opracowań także: R. de Vaux, The Early History of Israel (Philadelphia, PA: Westminister Press 1978) 193-200; A. Malamat, Mari and the Early Israelite Experience (Oxford: Oxford University Press 1989) 52-54; G. Buccellati, „From Khana to Lagê: The End of Syro-Mesopotamia”, De la Babylonie à la Syrie, eu passant par Mari. Mélanges offerts à J-R. Kupper (red. Ö. Tunca) (Liège: Université de Liège 1990) 229-253.

81 Blenkinsopp, Abraham, 28.

82 Por. J. Lemański, Księga Rodzaju. Rozdziały 1-11 (NKB.ST 1/1) (Częstochowa:Święty Paweł 2013) 509-510.

83 Lemański, Księga Rodzaju. Rozdziały 1-11, 510-511.

84 Jericke, Die Ortsangaben, 87-88.

85 B.J. Beitzel, „The Old Assyrian Caravan Road in the Mari Royal Archives”, Mari in Retrospect. Fifty Years of Mari and Mari Studies (red. G.D. Young) (Winona Lake, IN: Eisenbrauns 1992) 
(he - chet). Jej zmiana daje się jednak łatwo wyjaśnić na drodze historycznego rozwoju języka.

Pozostałe imiona członków rodziny Abrahama nie mają już charakteru toponimicznego, ale ich sens jest także sugestywny, jeśli chodzi o poszukiwanie korzeni biblijnego Abrahama. Najmniej powiedzieć możemy o imieniu Lota. Jego etymologia nie została bowiem wyjaśniona. Chodzi prawdopodobnie, podobnie jak przy imieniu Abrahama (Abiram: „wyniesiony/wywyższony ze względu na przodków” lub „mój przodek został wywyższony”86), o imię semickie (choryckie lub hurryckie; por. Rdz 36,20.22: plemię Lotan?). Genealogie biblijne w każdym razie prezentują go jako praojca Ammonitów i Moabitów (Rdz 19,30-38; potem także Pwt 2,9.19; Ps 83,9). Według genealogii Lot byłby potomkiem Harana $(\mathrm{Rdz} 11,27=\mathrm{P})$, a więc bratankiem patriarchy. Potem jednak $($ Rdz 11,28-29 = nie-P) nie akcentuje się już tej linearnej zależności. Najistotniejsze jest natomiast przekonanie, że Lot (ludy, które reprezentuje) przywędrował do Kanaanu wraz z Abrahamem, ale potem, z własnego wyboru, przeniósł się na drugą stronę Jordanu ( $\mathrm{Rdz} 13$ = nie-P).

Imiona żeńskie mają z kolei charakter przydomków. Sara/Saraj (chodzi raczej o warianty właściwe różnym dialektom) oznacza „księżniczkę"87. Słowo $\check{s}$ arrātu, łączone $\mathrm{z}$ etymologią tego imienia, to tytuł przynależny małżonce bóstwa księżyca, określanego imieniem Sin i czczonego w regionie pomiędzy Ur i Charanem aż po czasy Nabonida - ostatniego władcy Babilonii ${ }^{88}$. Podobne konotacje ma także imię przynależne do pierwszej z córek Harana - Milki. Łączone z jego etymologią słowo malkâtu - idąc śladem babilońskich konotacji - oznacza „królową”, a to kolejny, alternatywny sposób określania małżonki boga księżyca w tym regionie ${ }^{89}$. Nie znamy niestety właściwej etymologii imienia drugiej z córek Harana - Jiski. Sugerowane rdzenie to $n s k$ - „na-/polewać” (w odniesieniu do perfum) lub skh - „widzieć” (w odniesieniu do przychylności ze strony bóstwa $)^{90}$. Milka prezentowana jest jako żona Nachora, brata Abrahama i wuja Lota. Jiska, druga córka Harana, jest natomiast tylko wspomniana z imienia. Tradycja żydowska zapisana w midraszach (GenRab 38:14) i Józef Flawiusz (Ant. 1.151) identyfikują jednak jej imię jako alternatywne

35-57, zwł. 36, 38, 52; Fleming, „Mari”, 71; D. Frayne, „In Abraham's Footsteps”, The World of the Aramaeans. Biblical Studies in Honour of Paul-Eugène Dion (red. M. Doviau - J.W. Wevers M. Weigl) (Sheffield: Academic Press 2001) I, 225.

86 Lemański, Księga Rodzaju. Rozdziały 11,27-36,43, 93-94. Na jednej z list staroasyryjskich pojawia się także nazwa Abrum, jednak jej identyfikacja i lokalizacja jest niepewna; por. Beitzel, „The Old Assyrian", 36-37.

87 KBL, II, 374 (śārâ), 375 (śāraj).

88 Lemański, Ksiega Rodzaju. Rozdziaty 11,27-36,43, 95-96; Blenkinsopp, Abraham, 29.

89 Lemański, Księga Rodzaju. Rozdziały 11,27-36,43, 96; Jericke, Die Ortsangaben, 88; Blenkinsopp, Abraham, 29.

90 Lemański, Księga Rodzaju. Rozdziały 11,27-36,43, 96. 
dla imienia Saraj/Sara. Taka identyfikacja przekonuje Josefa Blenkinsoppa ${ }^{91}$. Argumentem jest dla niego fakt, że w tego typu strukturach obowiązuje pewnego rodzaju symetria i imię bez jakiejkolwiek funkcji w tekście nie miałoby sensu. Niemniej w Rdz 4,22, na zakończenie genealogii Kaina, także występuje - w drodze wyjątku - żeńskie imię córki Lameka, którym kończy się nieoczekiwanie cała „męska” genealogia. Brak dalszych odniesień w tym wypadku, wraz $\mathrm{z}$ wyjątkową w tej genealogii wzmianką o córce (potencjalnej rodzicielce), ma swoje znaczenie symboliczne. Oznacza brak przyszłości dla postaw reprezentowanych przez Lameka (por. Rdz 4,19.23-24 + Rdz 4,25-26: alternatywna linia Seta, pierwszego czciciela Jhwh). Zatem brak odniesień dla Jiski i w tym wypadku może oznaczać jedynie to, że mimo okazji nie stała się ona żoną drugiego z braci zmarłego Harana, co z kolei sugeruje, że Saraj - żona Abrahama - nie ma w związku z tym sprecyzowanych korzeni etnicznych. Z tekstu biblijnego w każdy razie nie wynika nic takiego, co sugerowałoby identyfikację Jiski i Saraj ${ }^{92}$.

Żeńskie imiona w genealogii Abrama zawierają zatem echo kultu bóstwa księżyca, znanego i praktykowanego w regionie pomiędzy Charanem i Ur do końca epoki babilońskiej, obecnego w tle tradycji o pochodzeniu Abrahama. Prawdopodobnie chronologicznie późniejszy tekst z Joz 24,2 wspomina w każdym razie o przodkach, którzy przed powołaniem Abrahama czcili za Eufratem innych bogów ${ }^{93}$. Trzeba także zauważyć, że krzyżówki małżeńskie w tak ścisłym kręgu rodzinnym (pomiędzy kuzynami), praktykowane przez Abrahama, Izaaka i Jakuba (por. Rdz 24,24; 29,12) były potem zakazane przez Prawo (Kpł 18,12-14). Z drugiej strony stanowiły zarazem coś naturalnego w społecznościach opartych na liniach patriarchalnych - kontynuacji osi ojciec-syn. W społecznościach tego rodzaju, nawet jeśli żony sprowadzano z zewnątrz, to spadkobierca, zwykle najstarszy syn, szukał jej w swoim kręgu rodzinnym tak, by zachować nie tylko bliskie pokrewieństwo, ale i wraz z tym - rodzinny etos oraz tradycyjną kulturę ${ }^{94}$.

91 Blenkinsopp, Abraham, 28-29.

92 Taka identyfikacja czyniłaby z Lota nie tylko bratanka, ale i szwagra Abrahama. Kiedy jednak potem Abraham tłumaczy się z tego, że przedstawiał swoją żonę jako siostrę (Rdz 20,12), wyjaśnia, że w istocie jest ona dla niego siostrą, gdyż jego ojciec jest zarazem jej ojcem (począł ją z inną żoną). W tym wypadku jednak Lot mógłby być bratem Sary/Jiski tylko pod warunkiem, że „ojciec” oznacza w ustach Abraham dziadka (Teracha zatem, a nie Harana).

93 Na temat tego tekstu por. H.N. Rösel, Joshua (HCOT) (Leuven - Paris - Walpole, MA: Peeters 2011) 365-366; S. Wypych, Księga Jozuego (NKB.ST 6) (Częstochowa: Święty Paweł 2015) 516-517.

94 Blenkinsopp, Abraham, 29. 


\section{Abraham - Amoryta?}

Region, z którym powiązane są etniczne i toponimiczne korzenie genealogii Abrahama, w czasach tworzenia list biblijnych zamieszkiwany był przez Aramejczyków (por. Rdz 24,10: Aram-Nacharaim - „Aram dwurzecza”"95; Rdz 28,2-7 [tekst P]: Paddan-Aram; Rdz 28,5: Laban, syn Betuela Aramejczyka). Tym być może należy tłumaczyć analizowane już etniczne powiązanie przodków Izraela z tą grupą semicką (por. Pwt 26,5a). Opublikowane pod koniec XX w. (1988) kolejne listy z Mari ${ }^{96}$ sugerują jednak, że Charan stanowił wcześniej amoryckie centrum plemienne. Czytamy tam między innymi o pewnej ceremonii: „Asdi-takim i królowie Zalmaqum wraz z przywódcami i starszymi Jaminitów zabili wspólnie osła w świątyni Sîn w Ḥarrān" (tł. własne na podstawie ARM 26). Jaminici to jedna $\mathrm{z}$ amoryckich grup plemiennych, zamieszkująca rejon Charanu (por. Lb 26,12; potem także Rdz 46,10; Wj 6,15; $1 \mathrm{Krn} 4,24)$. We wzmiankowanym tu rytuale część badaczy doszukuje się swego rodzaju ofiary przymierza, potwierdzającej utrwalenie/zawarcie wzajemnych stosunków i trwałość relacji plemiennych ${ }^{97}$ dokonane - co ważne - na terytorium Jaminitów, w Charanie.

Teksty biblijne traktująAmorytów jako pramieszkańców Kanaanu (Rdz 15,21; Wj 13,5). Niekiedy łączy się ich z górzystym centrum tego regionu (Lb 13,29; Pwt 1,7.44), a czasem z Zajordanią (Lb 21,13.26). Ezechiel mówi nawet, że ojcem (przodkiem) Izraela był Amoryta, a matką Chetytka (Ez 16,3), ale wypowiedź ta ma charakter polemiczny ${ }^{98}$. Niemniej w ludzie tym postrzega się jednego z wrogów Izraela, przeszkadzającego mu w drodze do Kanaanu (Lb 21,21-32). Imiona amoryckie w swej strukturze są północno-semickie i różnią się od imion akadyjskich ${ }^{99}$. Wiele informacji na ich temat wskazuje, że byli ludem nomadycznym, trudniącym się pasterstwem. Jeden z tekstów opisuje ich nawet jako

Lemański, Księga Rodzaju. Rozdziaty 11,27-36,43, 549.

G. Dossin - Ch.-F. Jean (red.) Archives epistolaires de Mari (Archives Royales de Mari 26/1.2; Paris: Librairie Oriemtaliste Guetner 1988) 24.

Por. też TUAT NF, III, 59-60.

Wspomniane tu kananejskie pochodzenie Jerozolimy (=symbol całego narodu) nawiązuje, na zasadzie polemiki, do historycznego credo z Pwt 26,5-10 i Joz 24,2-13. „Pogańskie początki” miasta reprezentują tu nie Jebusyci (Rdz 10,15-16; Sdz 19,11-12; 2Sm 5,6), lecz wspominani przez proroka Amoryci i Hetyci (por. Wj 3,8.17; Pwt 7,1) - dwie nacje symbolizujące w jego opinii najbardziej zdeprawowaną część ludzkości (por. Ez 16,44-45); por. też W. Pikor, Rola ziemi w przymierzu Boga z Izraelem. Studium historyczno-teologiczne Księgi Ezechiela (Lublin: Wydawnictwo KUL 2013) $182+$ przypis 34 . W drugim przypadku nie chodzi jednak prawdopodobnie o Hetytów z Anatolii, lecz autochtoniczną grupę etniczną zamieszkującą Kanaan; por. E. Lipiński, „Hittites et Hourittes dans la Bible", The BibAn 2/1 (2012) 9-25.

9 H.B. Huffmon, Amorite Personal Names in the Mari Texts: A Structural and Lexical Study (Baltimore, MD: John Hopkins University Press 1965). 
„mieszkańców namiotów (karmionych?) wiatrem i deszczem..."100. Odniesienia do Amorytów (Amurru) znikają z tekstów mezopotamskich w późnym okresie brązu. Wspomina się wówczas tylko ogólnie o regionie na zachodzie. Niemniej „królestwo Amorytów” w Syrii znane jest z korespondencji z el-Amarna, tekstów z Ugarit i tekstów odnalezionych w dawnej hetyckiej stolicy, w dzisiejszym Boğazköy (dawna Anatolia, dziś środkowa Turcja) ${ }^{101}$. Niektóre teksty z Mari wskazują jednak, że istniało ono o wiele wcześniej ${ }^{102}$. Położone było na wschód od Eufratu, w Syrii, pomiędzy Libanem i Damaszkiem.

Nie ma dziś natomiast zgody co do pochodzenia tego ludu. Według jednych byli oni nomadami żyjącymi na obrzeżach cywilizacji w regionie Eufratu, co wspierają choćby wspomniane powyżej odniesienia. Jednak według innych pierwotnie byli oni rolnikami operującymi w wąskim pasie środkowego Eufrat i poszerzającymi następnie swe terytoria poprzez wypas owiec. Spora część tekstów prezentuje ich jako lud żyjący poza kręgiem cywilizacji i kultury, półdziki, mieszkający na pustyni. Taka opinia ma jednak charakter stronniczy i może oddawać jedynie niechęć wobec tego ludu (por. Rdz 46,34), a nie rzeczywisty stan rzeczy ${ }^{103}$. Istotne dla nas jest to, że ich imiona, jak wspomnieliśmy, są semickie, język należy do grupy języków północno-semickich, jak hebrajski, aramejski, ugarycki i fenicki, a zwyczaje odpowiadają tym, które znamy z opisów patriarchalnych. Nawet jeśli wszystko to nie pozwala na jednoznaczne usytuowanie tradycji patriarchalnych w II tysiącleciu przed Chrystusem, gdyż takie same zwyczaje były kontynuowane także w I tysiącleciu, co zauważono już dawno ${ }^{104}$, to upoważnia mimo wszystko do doszukiwania się korzeni etniczno-geograficznych, $\mathrm{z}$ jakich mogły wyrosnąć te tradycje. Zatem powiązanie Charanu z rodziną Abrahama może mieć związek z tradycją o amoryckim pochodzeniem przodków mieszkańców Judei, choć nie da się tego dowieść w sposób jednoznaczny. Natomiast biblijne powiązanie przodków Izraela z Aramejczykami, poza wspominanymi już różnymi sugestiami, może wiązać się z faktem, że w czasach autora biblijnego region ten po prostu zajmowali właśnie Aramejczycy, a ich los stał się paradygmatem dla wszystkich tych, którzy doznawali ucisku od wielkich imperiów panujących w tym regionie.

100 G. Buccellati, The Amorites of the Ur III Period (Pubblicazioni del Seminario di Semitistica, Richerche 1) (Naples: Istituto Orientale di Napoli 1966) 92-93, 324-330.

101 I.J. Gelb, ,The Early History of the West Semitic Peoples”, JCS 15 (1961) 41-42.

102 Gelb, „The Early”, 47.

103 Grabbe, Ancient Israel, 47.

104 T.L. Thompson, The Historicity of the Patriarchs Narratives: The Quest for the Historical Abraham (BZAW 133; Berlin: de Gruyter 1974); Van Seters, Abraham. 


\section{Podsumowanie}

Czy jesteśmy zatem w stanie dotrzeć do historycznych korzeni tradycji o Abrahamie? Bezpośrednio nie. Abram - Abraham to lokalny przodek, z którym utożsamiali się mieszkańcy Judei. Najwcześniejsze biblijne wypowiedzi na jego temat poza Księgą Rodzaju pojawiają się dopiero w okresie wygnania babilońskiego (Ezechiel i Deutero-Izajasz). Z kolei z tradycji zachowanej w cyklu o Abrahamie (Rdz 11,27-25,11) wynika, że była ona kultywowana przede wszystkim w okolicach Hebronu (Mamre). Lista geograficzna Szeszonka I, faraona panującego pod koniec X tysiąclecia przed Chrystusem, zawiera nazwę miejsca (prawdopodobnie fortu) znajdującego się na Negebie i kojarzonego przez część badaczy z imieniem „Abram”. Niemniej identyfikacja, choć kusząca, nie jest pewna, a dziś dla większości jawi się wręcz jako mało przekonująca. Z tradycji biblijnych jakieś wnioski na temat potencjalnego pochodzenia Abrahama wysnuć można jedynie pośrednio, poprzez analizę skąpych danych egzegetycznych. Większość tradycji składających się na cykl o Abrahamie ma charakter literacko-teologiczny. W dużej mierze stanowi kompozycję autorów kapłańskich i niekapłańskich. Pierwsi tworzyli swoje teksty w okresie końca wygnania i później. Drugich identyfikuje się bądź jako środowisko odmienne od kapłańskiego, choć niekoniecznie wiele starsze niż kręgi kapłańskie, bądź jako autorów postkapłańskich. Wydobycie z tych tekstów śladów pierwotnej tradycji nie jest łatwe. Poza porównywaniem zwyczajów patriarchalnych z danymi o kulturze plemion półnomadycznych z Mezopotamii, jedną z możliwości jest analiza imion związanych z rodziną Arahama (Rdz 11,27-32). Mają one charakter toponimiczny (imiona męskie) i sugerują region Charanu położony pomiędzy rzekami Eufrat i Habur. Niektóre z imion żeńskie noszą z kolei cechy przydomków przynależnych bogini - żonie bóstwa księżyca Sin, czczonego w tym regionie aż do końca epoki babilońskiej. Na tej podstawie możemy sądzić, że „historyczny” Abraham (lub grupa, z którą należy go utożsamiać) pochodził prawdopodobnie z tego właśnie regionu. Kwestia tego, czy był Aramejczykiem, czy raczej Amorytą, jest trudniejsza do rozstrzygnięcia. Na terenie, gdzie znajdował się Charan, mieszkali pierwotnie Amoryci. Wiele związanych z nimi informacji dobrze wpisuje się w opisy biblijnych patriarchów. Niemniej zwyczaje patriarchalne równie dobrze pasują do II, co i do I tysiąclecia przed Chrystusem. W epoce żelaza (począwszy od około 1200 r. przed Chr.) na terenach tych dominowali już Aramejczycy. Teksty biblijne sugerują obie możliwości (Pwt 26,5a: Aramejczyk; Ez 16,3: Amoryta). Pierwsza z tych identyfikacji może mieć jednak charakter wtórny i symboliczny. Aramejczycy zamieszkiwali w I tysiącleciu przed Chrystusem tereny, z których wywodził się biblijny Abraham. Jednak przez długi czas (X-VIII w. przed Chr.) byli wrogami Izraela. Taka identyfikacja etniczna byłaby więc trudna. Po 732 r. przed Chr. ich 
państwo zostało zniszczone przez Asyryjczyków i zostali rozproszeni. Podobny los spotkał niedługo potem także Izraela (722/721 przed Chr.), a z czasem również Judę ze strony Babilończyków (597/587 przed Chr.). Wspólnota losów Aramejczyków i Izraelitów również mogła zatem wpłynąć na sugerowane aramejskie pochodzenie przodków narodu wybranego. W kontekście kanonicznym (z uwzględnieniem jednak danych krytycznoliterackich) można sądzić bowiem, że identyfikacja przodek-Aramejczyk (Pwt 26,5a) najpierw została odniesiona do Jakuba (Rdz 25,5b-9; por. Rdz 46,1-7) i dopiero ostatecznie dopasowana do Abrahama (Rdz 12,10-20). Jednak pierwotnie cała deklaracja mogła mieć sens wyłącznie ogólny i typologiczny (Aramejczykiem był ktoś pozbawiony nadziei na przyszłość, skazany na zagładę). W aktualnym kontekście (Pwt 26,5a.10a) taki los znajduje swoją przeciwwagę w deklaracji dziękczynnej za plony, dającej nadzieję na przyszłość.

Z kolei amoryckie korzenie w wypowiedzi proroka Ezechiela (Ez 16,3) także mogą mieć walor wyłącznie symboliczny (prorok w ten sposób deprecjonuje postawę Jerozolimy symbolizującej cały naród). O amoryckich korzeniach Abrahama możemy więc mówić jedynie na zasadzie wysoce prawdopodobnego domysłu, który sugeruje zestawienie danych historycznych o regionie Charanu i toponimiczne konotacje związanych z nim imion męskich członków jego rodziny.

\section{Bibliografia}

Aharaoni, Y., The Land of the Bible. A Historical Geography (Philadelphia, PA: Westminster Press 1979).

Ahituv, Sh., Canaanite Toponyms in Ancient Egyptian Documents (Jerusalem: Magnes Press, Hebrew University 1984).

Albright, W.F., Od epoki kamiennej do chrześcijaństwa (tł. E. Zwolski) (Warszawa: Pax 1967).

Altmann, P.A., „Feast, Femine and History: The Festival Meal Topos and Deuteronomy 26,1-15”, Zeitschrift für die alttestamentliche Wissenschaft 124 (2012) 555-567.

Andersen, K.T., „Noch einmal: Die Chronologie von Israel und Juda”, Scandinavian Journal of the Old Testament 3/1 (1989) 1-45.

Beek, M.A., „Das Problem des aramäisches Stammvaters (Deut XXVI 5)”, Oudtstamentische Studien 8 (1950) 193-212.

Beitzel, B.J., ,The Old Assyrian Caravan Road in the Mari Royal Archives”, Mari in Retrospect. Fifty Years of Mari and Mari Studies (red. G.D. Young) (Winona Lake, IN: Eisenbrauns 1992) 35-57.

Berlejung, A., „Geschichte und Religionsgeschichte des antiken Israels”, Grundinformation Altes Testament (red. J.C. Gertz) (Göttngen: Vandenhoeck \& Ruprecht 2006) 59-192.

Blenkinsopp, J., Abraham. The Story of a Life (Grand Rapids, MI - Cambridge: Eerdmans 2015).

Blum, E., Die Kompositon der Vätergeschichte (WMANT 57; Neukirchen-Vluyn: Neukirchener 1984). 
Bowman, R.A., „Arameans, Aramaic, and the Bible”, Journal of Near Eastern Studies 7 (1948) 65-90.

Brandscheidt, R., Abraham. Glaubenswanderschaft und Opfergang des von Gott Erwählten (Würzburg: Echter 2009).

Breasted, J.H., „The Earliest Occurrence of the Name of Abraham”, American Journal of Semitic Languages and Literatures 21 (1904) 22-36.

Breasted, J.H., „The 'Field of Abram' in the Geographical List of Sheshonk I”, Journal of the American Oriental Society 31/3 (1911) 290-295.

Buber, M., „The Prayer of the First Fruits”, On the Bible (red. N. Glatzer) (New York: Schocken 1968), 122-130.

Buccellati, G., The Amorites of the Ur III Period (Pubblicazioni del Seminario di Semitistica, Richerche 1; Naples: Istituto Orientale di Napoli 1966).

Buccellati, G., „From Khana to Lagê: The End of Syro-Mesopotamia”, De la Babylonie à la Syrie, eu passant par Mari. Mélanges offerts à J-R. Kupper (red. Ö. Tunca (Liège: Université de Liège 1990) 229-253.

Christensen, D.L., Deuteronomy 21:10-34:12 (WBC 6B; Nashville, TN: Nelson 2002).

Dossin, G. - Jean, Ch.-F. (red), Archives epistolaires de Mari (Archives Royales de Mari 26/1.2; Paris: Librairie Oriemtaliste Guetner 1988).

Durrand, J.-M., „Réalités amorrites et traditions bibliques”, Revue d'Assyriologie et d'Archéologie Orientale 92 (1998) 3-39.

Finkelstein, I. - Römer Th., „Comments on the Historical Background of the Abraham Narrative. Between 'Realia' and 'Exegetica', Hebrew Bible and Ancient Israel 3 (2014) 3-32.

Fleming, D.E., „Mari and the Possibilities of Biblical Memory”, Revue d'Assyriologie et d'Archéologie Orientale 92 (1998) 41-78.

Frayne, D., „In Abraham's Footsteps”, The World of the Aramaeans. Biblical Studies in Honour of Paul-Eugène Dion (red. M. Daviau - J.W. Wevers - M. Weigl) (Sheffield: Academic Press 2001) I, 216-236.

Gelb, I.J., „The Early History of the West Semitic Peoples”, Journal of Cuneiform Studies 15 (1961) $27-47$.

Gibson, J.C.L., „Light from Mari on the Patriarchs”, Journal of Semitic Studies 7 (1962) 44-62.

Gibson, J.C.L., „Observations on Some Important Ethnic Terms in the Pentateuch”, Journal of Near Eastern Studies 20 (1961) 217-238.

Godd, C.J., „Inscribed Prisms of Sargon II from Nimrud”, Iraq 16 (1954) 173-201.

Grabbe, L.L., Ancient Israel. What Do We Know and How Do We Know It (New York - London: Continuum 2007).

Hayes, J.H. - Hooker, P.K., A New Chronology for the Kings of Israel and Judah (Atlanta, GA: Knox 1988).

Hendel, R., Remembering Abraham. Culture, Memory, and History in the Hebrew Bible (Oxford: Oxford University Press 2005).

Herzog, Z., „Tel Beersheba”, The New Encyclopedia of Archaeological Excavations in the Holy Land (red. E. Stern) (New York: Simon \& Schuster 1993) I, 167-173.

Hoch, J.E., Semitic Words in Egyptian Texts of the New Kingdom and Third Intermediate Period (Princeton, NJ: Princeton University Press 1994).

Huffmon, H.B., Amorite Personal Names in the Mari Texts: A Structural and Lexical Study (Baltimore, MD: John Hopkins University Press 1965). 
Janowski, B. - Wilhelm, G. (red.), Texte aus der Umwelt des Alten Testament. Neue Folge, (Gütersloh: Gütersloher Verlagshaus 2005-2006) II-III (= TUAT NF).

Jericke, D., Die Ortsangaben im Buch Genesis. Ein historisch-topographischer und literarisch-topographischer Kommentar (FRLANT 248; Göttingen: Vandenhoeck \& Ruprecht 2013).

Kitchen, K.A., The Third Intermediate Period in Egypt (1100-650 B.C.E.) (Warminster: Aris \& Phillips 1986).

Köckert, M., Vätergott und Väterverheissungen: Eine Auseinandersetzung mit Albrecht Alt und seinen Erben (FRLANT 142; Göttingen: Vandenhoeck \& Ruprecht 1988).

Köckert, M., „Wie wurden Abraham- und Jakobüberlieferung zu einer «Vätergeschichte» verbunden?", Hebrew Bible and Ancient Israel 3 (2014) 43-66.

Koehler, L. et al. (red), Wielki stownik hebrajsko-polski i aramejsko-polski Starego Testamentu (Warszawa: Vocatio 2008) I-II (=KBL).

Kratz, R.G., „Die Verheissungen an die Erzväter. Die Konstruktion ethnischer Identität Israels”, The Politics of the Ancestors (red. M.G. Brett - J. Wöhrle) (FAT 124; Tübingen: Mohr Siebeck 2018) 35-66.

Kreuzer, S., Die Frühgeschichte Israels in Bekenntnis und Verkündigung des Alten Testaments (BZAW 178; Berlin - New York: de Gruyter 1989).

Kyle, M.G., „The 'Field of Abram' in the Geographical List of Shoshenq I”, Journal of the American Oriental Society 31/1 (1911) 86-92.

Kwiatkowski, B., Poczet faraonów. Życie, legenda, odkrycia (Warszawa: Iskry 2002).

Lemański, J., „Abraham versus Jakub”, Collectanea Theologica 88/4 (2018) 35-51.

Lemański, J., Księga Rodzaju. Rozdziały 1-11 (NKB.ST 1/1; Częstochowa: Święty Paweł 2013).

Lemański, J., Księga Rodzaju. Rozdziały 11,27-36,43 (NKB.ST 1/2; Częstochowa: Święty Paweł 2014).

Lemański, J., „W poszukiwaniu tradycji o Izaaku”, Colloquia Theologica Ottoniana 2 (2013) 63-76.

Lemche, N.P., „Habiru, Hapiru”, The Anchor Bible Dictionary (red. D.N. Freedman) (New York: Doubleday 1992) III, 6-10.

Lemche, N.P., The Israelites in History and Tradition (London - Loiusville, KY: Westminster John Knox Press 1998).

Lipiński, E., „Hittites et Hourittes dans la Bible”, The Biblical Annals 2/1 (2012) 9-25.

Lipiński, E., Studia z dziejów i kultury starożytnego Bliskiego Wschodu (Kraków: Nomos 2013).

Luckenbill, D.D., „The 'Wandering Aramaean”, American Journal of Semitic Languages and Literatures 36 (1919-1920) 281-312.

Lundbom, J.R., Deuteronomy. A Commentary (Grand Rapids, MI - Cambridge: Eerdmans 2013).

Malamat, A., Mari and the Early Israelite Experience (Oxford: Oxford University Press 1989).

Mayes, A.D.H., Deuteronomy (Grand Rapids, MI - London: Eerdmans 1981).

Mazar, B., „The Campaign of Pharao Shishak to Palestine”, Volume du Congrès. International pour l'Étude de l'Ancien Testament, Strassbourg 1956 (VTSup 4; Leiden: Brill 1957) 57-66.

Mazar, B., „Pharaoh Shishak's Campaign to the Land of Israel”, The Early Biblical Period: Historical Studies (red. S. Ahituv - B.A. Levine) (Jerusalem: Israel Exploration Society 1986) 39-50.

Mazar, A., Archaeology of the Land of the Bible 10,000-586 B.C.E. (New York: Doubleday 1990).

Morenz, L.D., „Reconsidering Sheshonk's Emblematic List and His War in Palestine”, Moving across Borders. Foreign Relations, Religion and Cultural Interactions in the Ancient Mediterranean (red. P. Kosoulis - M. Magliveras) (OLA 159; Löwen: Peeters 2007) 101-118. 
Mühling, A., ,Blickt auf Abraham euren Vater”. Abraham als Identifikationsfigur des Judentums in der Zeit des Exils und des Zweiten Tempels (FRLANT 236; Göttingen: Vandenhoeck \& Ruprecht 2011).

Murphy-O’Connor, J., Przewodnik po Ziemi Świętej, wyd. 2 (Warszawa: Vocatio 1999).

Negev, A. (red.), Encyklopedia archeologiczna Ziemi Świętej (tt. O. Zienkiewicz) (Warszawa: Da Capo 2002).

Nelson, R.D., Deuteronomy. A Commentary (Louisville, KY - London: Westminster John Knox Press 2002).

Nielsen, E., Deuteronomium (HAT 1/6; Tübingen: Mohr \& Siebeck 1995).

Norin, S., „Ein Aramäer, dem Umkommen Nahe - ein Kontext der Forschung und Tradition”, Scandinavian Journal of the Old Testament 8 (1994) 87-104.

Noth, M., „Die Wege der Pharaonenheere in Palästina und Syrien: Untersuchungen palästinischen und syrischen Städte IV: Die Schoschenkliste", Aufsätze zur biblischen Landes und Altertumskunde (red. H.W. Wolf) (BTG; Neukirchen-Vluyn: Neukirchener Verlag 1971) 79-93.

Otto, E., Deuteronomium 23,16-34,12 (HThKAT; Freiburg - Basel - Wien: Herder 2017).

Pikor, W., Rola ziemi w przymierzu Boga z Izraelem. Studium historyczno-teologiczne Ksiegi Ezechiela (Lublin: Wydawnictwo KUL 2013).

de Pury, A., „Abraham, the Priestly Writer's 'Ecumenical' Ancestor”, Rethinking the Foundations. Historiography in the Ancient World and in the Bible. FS. J. Van Seters (red. S.L. McKenzie Th. Römer) (BZAW 293; Berlin - New York: de Gruyter 2000) 163-181.

Rom-Shiloni, D., „When an Explicit Polemic Initiates a Hidden One: Jacob's Aramaic Identity”, Words, Ideas, Worlds. FS Y. Amit (red. A. Brenner - F.H. Polak) (Sheffield: Sheffield Phoenix Press 2012) 206-235.

Rose, M., 5. Mose. Teilband 2: 5 Mose 1-11 und 26-34. Rahmenstücke zum Gesetzeskorpus (ZBK.AT 5.2; Zürich: Theologischer Verlag 1994).

Rösel, H.N., Joshua (HCOT; Leuven - Paris - Walpole, MA: Peeters 2011).

Schneider, Th., Leksykon faraonów (Warszawa - Kraków: Wydawnictwo Naukowe PWN 2001).

Schüle, A., Israels Sohn - Jahwes Prophet. Ein Versuch zum Verhältnis von kanonischer Theologie und Religionsgeschichte anhand der Bileam-Perikope (Num 22-24) (ATM 7; München: LIT 2001).

Ska, J.-L., „Essai sur la nature et signification du cycle d'Abraham (Gn 11,27-25,11)”, Studies in the Book of Genesis. Literature, Redaction and History (BETL 155; Leuven: University Press 2001) 153-177.

Spiegelberg, W., Aegyptologische Randglossen zum Alten Testament (Strassburg: Schlesier \& Schweikhardt 1904).

Thompson, T.L., The Historicity of the Patriarchs Narratives: The Quest for the Historical Abraham (BZAW 133; Berlin: de Gruyter 1974).

Tigay, J.H., Deuteronomy (JPS Torah Commentary; Philadelphia, PA: Jewish Publication Society 1996). Van Seters, J., Abraham in History and Tradition (New Haven, CT - London: Yale University Press 1975).

de Vaux, R., The Early History of Israel (Philadelphia, PA: Westminister Press 1978).

Warzecha, J., Historia dawnego Izraela (Warszawa: Wydawnictwo UKSW 2005).

Weinfeld, M., The Promise of the Land (Barheley, CA: University of California Press 1993).

Weippert, M., Historisches Textbuch zum Alten Testament (Grundrisse zum Alten Testament 10; Göttingen: Vandenhoeck \&Ruprecht 2010). 
Wevers, J.W., Notes on the Greek Text of Deuteronomy (SBL.SCSS 39; Atlanta, GA: Scholars 1995).

Wilson, K.A., The Campaign of Pharao Shoshenq I into Palestine (FAT 2/9; Tübingen: Mohr Siebeck 2005).

Wypych, S., Księga Jozuego (NKB.ST 6; Częstochowa: Święty Paweł 2015).

Zakovitch, Y., „My Father Was a Wandering Aramean' (Deuteronomy 26:5) or 'Edom Served My Father'?", [w:] Mishneh Todah. Studies in Deuteronomy and Its Cultural Environment. FS. J.H. Tigay (red. N.S. Fox et al.) (Winona Lake, IN: Eisenbrauns 2009) 133-137. 